Дун Чживей, стажер-дослідник (Вінницький національний технічний університет, м. Вінниця)

\title{
КОНЦЕПТУАЛЬНИЙ ПІДХІД ФОРМУВАННЯ ЗАСАД РОЗВИТКУ НАЦІОНАЛЬНОЇ ОСВІТИ
}

У статті на основі чинного законодавства України досліджено види освіти такі, як формальна, неформальна та інформальна. Проведено характеристику способів організації навчання за визначеними видами. Виокремлено основні проблеми сучасної освітньої політики і запропоновано шляхи забезпечення розвитку освітньої галузі національної економіки. Запропонований концептуальний підхід формування засад розвитку національної освіти. Побудовано підхід до аналізу економічних тенденцій освітньої галузі 3 урахуванням абсолютних i питомих показників, що дозволить виявити внутрішні $\mathbf{i}$ стратегічні проблеми галузі та дасть змогу сформувати конкретні регулюючі заходи стосовно підвищення якості освітніх послуг i модернізації всієї системи освіти.

Ключові слова : національна економіка, освіта, освітня сфера, освітня політика, освітня реформа, види освіти, способів організації навчання, секторальний аналіз.

Формування і використання освітнього потенціалу $є$ запорукою побудови інноваційної та конкурентоспроможної національної економіки. Це обумовлює мету сучасної освіти - всебічний розвиток людини як особистості, іï інтелектуальних та інших здібностей, необхідних як для успішної самореалізації так і для виконання управлінських та виробничих функцій економіки. Тому, в контексті забезпечення економічного зростання країни, основним пріоритетом держави $€$ створення ефективної системи забезпечення розвитку освітньої галузі.

Дослідженням проблем функціонування і розвитку освітньої галузі займались такі вчені, А. М.Гуржій, В.Г.Кремень, С. Ю. Кучеренко, В.І. Луговий, Ю. О. Молчанова, С. Г. Натрошвілі, Н. Г. Протасова., О. Я. Савченко, Н. Б. Савіна та ін.

Водночас недостатньо дослідженими залишаються питання, що стосуються формування комплексного підходу до розвитку національної освіти. Необхідність вирішення зазначених проблем визначила мету даного дослідження.

Мета дослідження - в межах теоретичних досліджень 
запропонувати засади розвитку національної освіти.

Натрошвілі С.Г. у монографії «Стратегічне управління вищим навчальним закладом: теорія, методологія, практика», виокремлюючи умови підвищення якості національної вищої освіти зазначає, що це «посилення відповідальності освітніх закладів за результати своєї діяльності на основі розширення демократичних засад функціонування та поглиблення університетської автономії» [1, С. 122]. У Законі України «Про освіту» зазначено інші важливі умови, зокрема, щоб «кожен навчальний заклад мав внутрішню систему забезпечення якості освіти, яка складається з конкретних елементів: стратегія (політика) та процедури забезпечення якості освіти; система та механізми забезпечення академічної доброчесності; оприлюднені критерії, правила і процедури оцінювання здобувачів освіти; оприлюднені критерії, правила і процедури оцінювання педагогічної (науково-педагогічної) діяльності педагогічних та науково-педагогічних працівників; критерії, правила і процедури оцінювання управлінської діяльності керівних працівників закладу освіти; забезпечення наявності необхідних ресурсів для організації освітнього процесу, в тому числі для самостійної роботи здобувачів освіти; забезпечення наявності інформаційних систем для ефективного управління закладом освіти; створення в закладі освіти інклюзивного освітнього середовища, універсального дизайну та розумного пристосування; інші процедури та заходи, що визначаються спеціальними законами або документами закладу освіти» [2].

Процес реформування освітньої галузі в Україні розпочато у 2014 році і він триває дотепер. Освітня реформа базується на засадах Болонського процесу й інших важливих Законах України, а саме: «Про вищу освіту» [3], «Про наукову і науково-технічну діяльність» [4], «Про освіту» [2]. Ці акти освітнього законодавства продовжують процес системного удосконалення законодавчої бази української освіти. Так, за чинним законодавством, громадяни України можуть реалізовувати своє право на освіту впродовж життя шляхом формальної, неформальної та інформальної освіти (рис. 1).

Отже, чинне на сьогодні законодавство має чітко визначену класифікацію видів освіти. Згідно такої класифікації громадяни України реалізовують своє право на освіту, обираючи формальне, неформальне та інформальне навчання. Стосовно інформального виду навчання хотілося б додати, що результати навчання визнаються в системі формальної освіти в порядку, визначеному законодавством. 


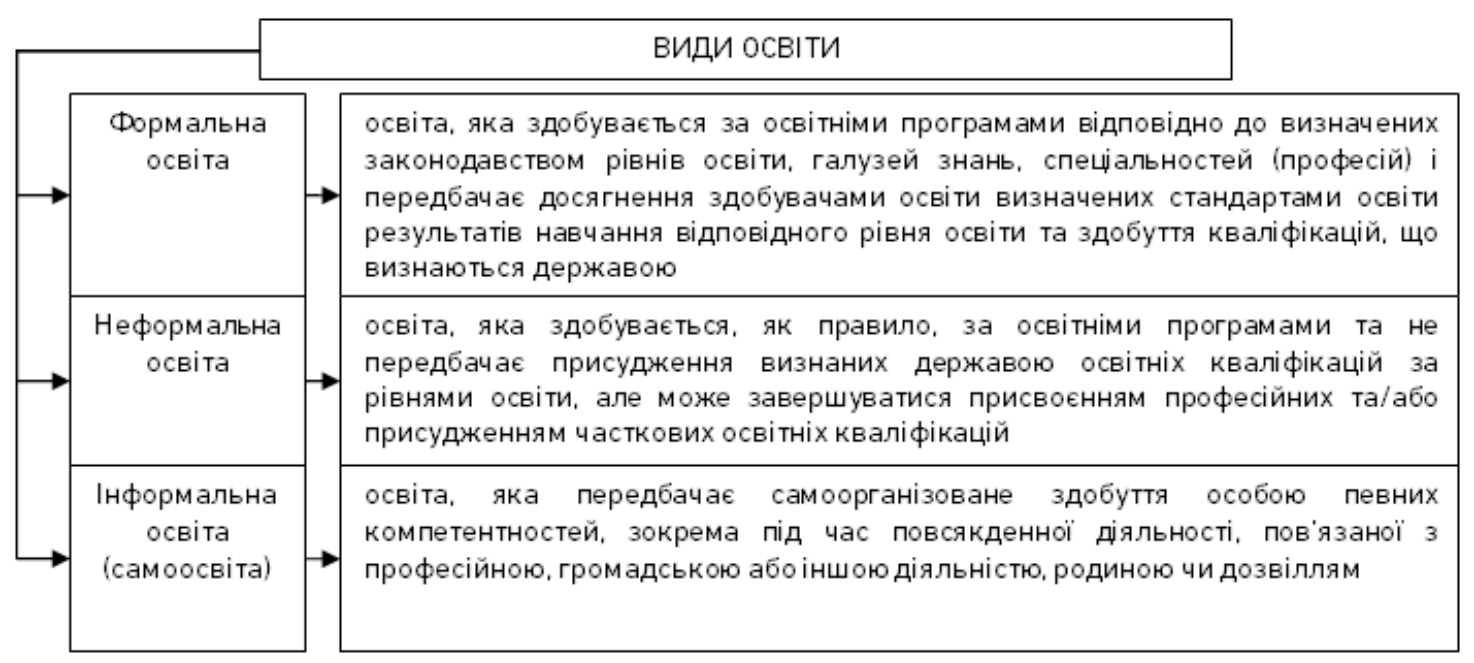

Рис. 1. Види освіти (згруповано автором на основі джерел [2; 5, С. 57])

Згідно 3 новітнім законодавством, «...особа має право здобувати освіту в різних формах або їх поєднувати» [2, Ст. 380]. Основні форми здобуття освіти в Україні подано в табличній формі (таблиця).

Стосовно організації різних форм здобуття освіти, поданих в таблиці, то відповідно до статті 9 Закону України «Про освіту» «...загальна середня освіта може бути організована за такими формами: інституційна (очна (денна, вечірня), заочна, дистанційна, мережева); індивідуальна (екстернатна, сімейна (домашня), педагогічний патронаж)» [2].

Міністерство освіти і науки України дає такі роз'яснення закладам освіти щодо інклюзивної освіти: «... «інклюзивна форма» здобуття освіти законодавством не передбачена. Для осіб 3 особливими освітніми потребами організовується інклюзивне навчання за денною або вечірньою формами здобуття освіти. Крім того, стан здоров'я може бути підставою для вибору здобувачами освіти (їх батьками) екстернату, педагогічного патронажу дистанційної форми» [11].

Законодавство надає можливості індивідуалізованого навчання. Тут йдеться про «здобуття освіти за екстернатною формою (екстернат), сімейною (домашньою) формою та педагогічним патронажем. При цьому розробники зауважують, що для забезпечення індивідуальної форми здобуття освіти можуть використовуватися технології дистанційного навчання» [12]. 
Форми здобуття освіти в Україні*

\begin{tabular}{|c|c|c|}
\hline $\begin{array}{l}\text { № } \\
3 / \Pi\end{array}$ & $\begin{array}{c}\text { Назва форм } \\
\text { здобуття освіти }\end{array}$ & Характеристика способу організації навчання \\
\hline 1. & Інституційна: & \\
\hline \multirow[t]{2}{*}{-} & очна & \multirow[t]{3}{*}{ передбачає їх безпосередню участь в освітньому процесі } \\
\hline & денна & \\
\hline- & вечірня & \\
\hline- & заочна & $\begin{array}{l}\text { поєднання очної форми освіти під час короткочасних сесій і самостійного } \\
\text { оволодіння освітньою програмою у проміжку між ними }\end{array}$ \\
\hline- & дистанційна & $\begin{array}{l}\text { індивідуалізований процес здобуття освіти, який відбувається в основному } \\
\text { за опосередкованої взаємодії віддалених один від одного учасників } \\
\text { освітнього процесу у спеціалізованому середовищі, що функціонує на базі } \\
\text { сучасних психолого-педагогічних та інформаційно-комунікаційних } \\
\text { технологій }\end{array}$ \\
\hline- & мережева & $\begin{array}{l}\text { оволодіння освітньюю програмою відбувається за участю різних суб'єктів } \\
\text { освітньої діяльності, що взаємодіють між собою на договірних засадах }\end{array}$ \\
\hline \multirow[t]{2}{*}{2.} & Індивідуальна: & \\
\hline & екстернатна & $\begin{array}{l}\text { освітня програма повністю засвоюється здобувачем самостійно, а } \\
\text { оцінювання результатів навчання та присудження освітньої кваліфікації } \\
\text { здійснюються відповідно до законодавства }\end{array}$ \\
\hline- & $\begin{array}{c}\text { сімейна } \\
\text { (домашня) }\end{array}$ & $\begin{array}{l}\text { організація освітнього процесу дітей самостійно їхніми батьками для } \\
\text { здобуття формальної (дошкільної, повної загальної середньоі) та/або } \\
\text { неформальної освіти. Відповідальність за здобуття освіти дітьми на рівні не } \\
\text { нижче стандартів освіти несуть батьки. Оцінювання результатів навчання та } \\
\text { присудження освітніх кваліфікацій здійснюються відповідно до } \\
\text { законодавства }\end{array}$ \\
\hline- & $\begin{array}{c}\text { педагогічний } \\
\text { патронаж }\end{array}$ & $\begin{array}{l}\text { спосіб організації освітнього процесу педагогічними працівниками, що } \\
\text { передбачає забезпечення ними засвоєння освітньої програми здобувачем } \\
\text { освіти, який за психофізичним станом або з інших причин, визначених } \\
\text { законодавством, зокрема з метою забезпечення доступності здобуття освіти, } \\
\text { потребує такої форми }\end{array}$ \\
\hline- & $\begin{array}{l}\text { на робочому місці } \\
\text { (на виробництві) }\end{array}$ & $\begin{array}{l}\text { спосіб організації навчання здобувачів освіти, завдяки якому оволодіння } \\
\text { освітньою програмою (як правило, професійної (професійно-технічної), } \\
\text { фахової передвищої освіти) відбувається на виробництві шляхом } \\
\text { практичного навчання, участі у виконанні трудових обов'язків і завдань під } \\
\text { керівництвом фахівців-практиків, залучених до освітнього процесу }\end{array}$ \\
\hline 3. & Дуальна & $\begin{array}{l}\text { передбачає поєднання навчання осіб у закладах освіти (в інших суб'єктів } \\
\text { освітньої діяльності) з навчанням на робочих місцях на підприємствах, в } \\
\text { установах та організаціях для набуття певної кваліфікації, як правило, на } \\
\text { основі договору }\end{array}$ \\
\hline
\end{tabular}

Джерело: складено на соснові [2; 11-12]

Група науковців Протасова Н. Г., Луговий В. І., Молчанова Ю. О., досліджуючи сучасний стан реформування системи освіти України, зауважують, що «відбуваються зміни в усіх ї̈ підсистемах, ланках тощо, при цьому зміст реформ, що запроваджуються в освіті, зумовлений не лише об'єктивними вимогами часу, а й станом самої системи освіти. Інтеграція вітчизняної системи освіти в глобальний світовий, зокрема європейський, освітній простір, адаптація системи освіти до нових соціально-економічних відносин, необхідність забезпечення конкурентоспроможності освіти в інформаційному суспільстві, переорієнтація освітнього процесу на розвиток особистості тощо вимагають модернізації системи управління освітою» [6]. 
Проблемним для України залишається така складова циклу освітньої політики, як оцінювання результатів, хоча системне оцінювання має не лише підвищити ії ефективність у тривалій перспективі, але й $€$ важливим для розроблення практичних та ефективних варіантів політики (ОЕСР, 2015 р.) [7, С. 21].

У Національній доповіді про стан і перспективи розвитку освіти в Україні зазначено, що «головною проблемою економічних відносин у сфері освіти України $\epsilon$ невідповідність діючого в освіті економічного механізму засадам ринкової економіки - як і за часів планової радянської економіки, державні кошти на освіту виділяються на утримання державних i комунальних навчальних закладів як бюджетних установ, а не на оплату конкретних видів освітніх послуг з урахуванням їх якості, вироблених і наданих закладами освіти як повноправними суб'єктами господарювання» [7, С. 22].

У звіті щодо реформи вищої освіти України охарактеризовані сучасні освітні умови в Україні, зокрема: «...переважна більшість студентів та абітурієнтів їдуть в Європу та США для того, щоб не лише здобути вищу освіту, а й стати потенційно повноцінним громадянином тої чи іншої країни. На жаль, залишаються практично одиниці тих, хто хоче використати отриманий досвід на теренах рідної країни. Можемо сміливо припустити, що потік студентів, які хочуть покинути рідну країну та виїхати навчатися за кордон, 3 кожним роком буде лише збільшуватися. I триватиме це доти, доки суспільство, держава не зрозуміє, що освіта, її якість $є$ майбутнім України, її культурним надбанням» [13].

Доцільно відмітити, що з 2017 року в українських школах запроваджено 12-річне навчання, яке поділяється на три періоди: 4 роки початкової школи; 5 років базової середньої школи; 3 роки профільної середньої школи. Старша профільна школа матиме ліцеї академічного та професійного спрямування. В академічних ліцеях учні поглиблюватимуть знання для вступу до вищих навчальних закладів. У професійних ліцеях, крім загальної середньої освіти, вони отримуватимуть першу професію. Після завершення кожного з рівнів результати оцінюватимуться шляхом державної підсумкової атестації, яка може здійснюватися у вигляді зовнішнього незалежного тестування. Однак для учнів молодшої школи така атестація здійснюватиметься лише для моніторингу. Загалом, освітня реформа передбачає, що головною метою навчання стане оволодіння учнями певним набором компетентностей та вмінь [11$13]$.

Шаховська А. обґрунтовує пріоритетні завдання сталого 
розвитку в освіті, серед яких виділяє «розробку спеціальних освітніх програм, розрахованих на сталий розвиток; впровадження педагогічних умов, створення моделей нової педагогічної культури та педагогічного змісту; постійне вдосконалення базису знань та забезпечення постійної інформованості населення з питання сталого розвитку» [8].

Роль техніки в сфері освіти полягає в звільненні від влади природи, а технологія - це своєрідне «стиснення» часу шляхом досягнення результату за оптимально короткий час. Більш того, сама наука в суспільній свідомості перетворилася в теоретичну основу технічних розробок. На перспективу для розвитку освітніх процесів країна має володіти методами високотехнологічного способу впливу на освітню дійсність, прогресивної організації суспільства та інститутів держави за рахунок вивільнення потенціалу громадян. Успіх цього значною мірою залежить від еволюції розвитку самого суспільства, культури та людини через соціалізацію та індивідуалізацію, розвиток свідомості, ускладнення поведінки, урізноманітнення способів діяльності та форм існування, запуск соціальних ліфтів тощо. Також, необхідною умовою є запровадження прозорих процедур та контролю наукової громадськості, що призводить до переносу корупційних процедур і правил, що існують у взаємовідносинах окремих бізнес структур і влади на наукову i освітню спільноти, створюючи помилкові уявлення про моральне обличчя ученого і учителя, що задає непоправної шкоди науковій та освітній спільноті, підриваючи довіру суспільства до неї.

Отже, для ефективної системи освіти, на сучасному етапі доцільним є: «запровадження незалежної професійної сертифікації, реформування системи атестації та підвищення кваліфікації педагогічних працівників; реформування системи управління та фінансово-економічного механізму функціонування системи освіти в Україні; запровадження зовнішнього незалежного оцінювання результатів навчання, здобутих на кожному освітньому рівні, в тому числі 3НО; розвиток альтернативних освітніх проєктів; розширення використання сучасних технологій в управлінні освітою, організації освітнього процесу і контролі результатів навчання та впровадження автоматизованих інформаційних систем; розробку та впровадження пілотних проектів» [9].

Головний радник з планування та науково-дослідної діяльності Королівського мельбурнського технологічного інституту А. Кальдерон прогнозує, що «протягом декількох таких десятиліть система вищої освіти стане на шлях безпрецедентних змін і перетворень незалежно від швидкості зміни екосистеми, в умовах якої вища освіта функціонує. Існує цілий ряд факторів, від розвитку 
технологій до урбанізації, вплив яких у найближчі роки визначить характер вищої освіти в глобальному масштабі, режим її надання, а також правила гри учасників та зацікавлених осіб. У найближчі 2550 років мегатренди, які будуть впливати на вищу освіту в глобальному масштабі, обумовлені поєднанням результатів подій, що відбулися, з одного боку, і реакцій на ці події з боку держав, суспільств, ринків і самих вищих навчальних закладів 3 іншого боку». У цьому ж прогнозі автор звертає увагу на освітні та кваліфікаційні стандарти, зазначаючи, що «...вони стануть типовими і усередненими для країн - торговельних партнерів. Ця тенденція посилить міжнародну студентську мобільність, при цьому вартість програм навчання, репутація та імідж освітньої установи таким же чином будуть впливати на кінцевий вибір студентів. Отже, вища освіта, має не тільки готувати індивіда до майбутньої професії, а й навчати базових аналітичних навичок і критичного мислення, розвивати здібності до самонавчання, вміння знаходити та фільтрувати потрібну інформацію, протистояти відтворенню стереотипів та ідеологічних конструктів. Зрештою, будь-яке самоуправління на місцях і розширення демократії має сенс лише за умови достатнього рівня освіченості населення, в іншому випадку це ніяким чином не перешкоджає маніпулюванню громадською думкою з боку тих, хто займає владні позиції та має відповідні ресурси» [10].

Загалом для проведення аналізу освітньої галузі національної економіки пропонуємо таку методику його проведення (рис. 2).

Отже, запропонований концептуальний підхід формування засад розвитку національної освіти. Запропонований підхід складається із трьох складових, зокрема: теоретичної, аналітичної і практичної.

Теоретична складова до свого складу включає:

- принципи освіти: доступність для кожного; рівність умов; гуманізм, демократизм, пріоритетність загальнолюдських цінностей; незалежність освіти від політичних партій та ін. організацій; інтеграція з наукою і виробництвом;

- взаємозв'язок з освітою інших країн; безперервність освіти; поєднання державного управління і громадського самоврядування в освіті;

- методи:

- адміністративно-правові методи: нормативно-правове регулювання освіти; державний сектор і державна власність в освіті; прояви державної монополії в освіті; державні інвестиції у розвиток освіти; 


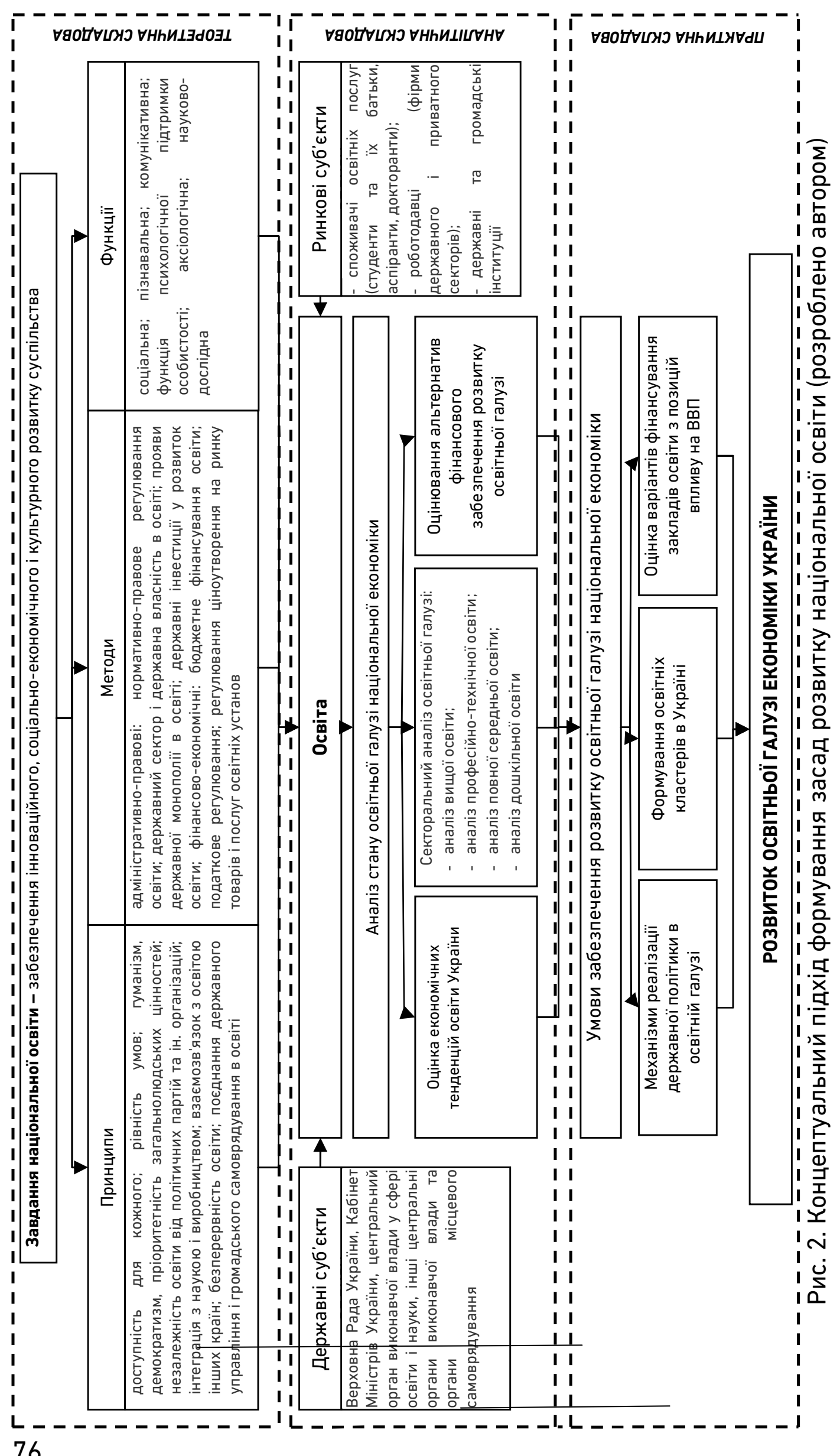


- фінансово-економічні: бюджетне фінансування освіти; податкове регулювання; регулювання ціноутворення на ринку товарів і послуг освітніх установ;

- функції:

- соціальна;

- пізнавальна;

- комунікативна;

- функція психологічної підтримки особистості;

- аксіологічна;

- науково-дослідна.

Таким чином, теоретична складова ґрунтується на головному завданні національної освіти - забезпечення прогресивного розвиту суспільства, яке у свою чергу побудоване на фундаментальних принципах, методах і функціях освіти. Означене дало змогу дослідити світовий досвід розвитку освіти в країнах $Є С$ і визначити концепцію розвитку української освіти з метою інтеграції систем освіти в єдину європейську систему.

Аналітична складова передбачає використання аналізу економічних тенденцій освітньої галузі, а саме: зведені витрати на освіту, витрати на освіту у відсотках до ВВП, державне забезпечення асигнування на освіту у розрізі фінансування і недофінансування освітньої галузі, ВВП освітньої галузі тощо. Це дозволяє виявити зовнішні і внутрішні проблеми галузі 3 метою формування регулюючих заходів стосовно модернізації всієї галузі освіти.

Також, аналітична складова включає проведення секторального аналізу галузі у розрізі: вищих навчальних закладів, професійно-технічних закладів, загальноосвітніх закладів, дошкільних навчальних закладів. Секторальний наліз виявляє проблеми у кожному секторі освітньої галузі і забезпечує базу для проведення перспектив розвитку освіти.

Оцінювання альтернатив фінансового забезпечення розвитку освітньої галузі ґрунтується на статистичних даних зведених видатків на освіту та ВВП освітньої галузі за аналізований період: на вищу освіту; на професійно-технічну освіту; на загальну середню освіту; на дошкільну освіту. Прогноз ВВП освітньої галузі визначає такі моделі зв'язку ВВП освітньої галузі та зведених видатків на: вищу освіту; професійно-технічну освіту; загальну середню освіту; дошкільну освіту. Дана складова дозволяє виділити той рівень освіти, який найбільшою мірою впливає на максимальне прогнозне значення ВВП за видом економічної діяльності «Освіта».

Запропоноване аналізування стану освіти національної 
економіки виконується із врахуванням державних і ринкових суб'єктів впливу на галузь. Так, до ринкових суб'єктів впливу відносяться:

- споживачі освітніх послуг (студенти та їх батьки, аспіранти, докторанти);

- роботодавці (фірми державного і приватного секторів);

- державні та громадські інституції.

Державні суб'єкти впливу:

- Верховна Рада України;

- Кабінет Міністрів України;

- центральний орган виконавчої влади у сфері освіти і науки;

- інші центральні органи виконавчої влади та органи місцевого самоврядування.

Практична складова - це результативний етап дослідження, який включає умови забезпечення розвитку освітньої галузі національної економіки. Такими умовами є: розробка механізму реалізації державної політики в освітній галузі; формування освітніх кластерів в Україні; оцінка варіантів фінансування закладів освіти 3 позицій впливу на ВВП.

Отже, виконання приведених умов забезпечить не тільки розвиток освітньої галузі національної економіки, а й інноваційний, соціально-економічний і культурний розвиток всього українського суспільства.

1. Натрошвілі С. Г. Стратегічне управління вищим навчальним закладом : теорія, методологія, практика : монографія. Київ : КНУТД, 2015. 320 с. 2. Про освіту : Закон України від https://zakon.rada.gov.ua/laws/show/2145-19 (дата звернення: 05.01.2020). 3. Про вищу освіту : Закон України від 01.07.2014 р. № 1556-VII. URL: https://zakon.rada.gov.ua/laws/show/1556-18 (дата звернення: 05.01.2020). 4. Про наукову і науково-технічну діяльність : Закон України від 24.11.2015 р. № 848-VIII. URL: https://zakon.rada.gov.ua/laws/show/848-19 (дата звернення: 05.01.2020). 5. Кучеренко С. Ю. Сучасний стан, тенденції та проблеми розвитку освіти в Україні. Економічний вісник університету. 2018. Вип. 36(1). С. 51-59. URL: http://nbuv.gov.ua/UJRN/ecvu_2018_36\%281\%29_8 (дата звернення: 15.01.2020). 6. Протасова Н. Г., Луговий В. І., Молчанова Ю. О. Реформування освіти в Україні: державно-управлінський аспект : навч.-наук. вид. Київ ; Львів : НАДУ, 2012. 456 с. 7. Національна доповідь про стан і перспективи розвитку освіти в Україні. Нац. акад. пед. наук України / редкол.: В. Г. Кремень (голова), В. І. Луговий (заст. голови), А. М. Гуржій (заст. голови), О. Я. Савченко (заст. голови)] ; за заг. ред. В. Г. Кременя. Київ : Педагогічна думка, 2016. 448 с. 8. Шаховська А. Освітні аспекти сталого розвитку України. Наукові записки Кіровоградського державного педагогічного університету імені Володимира Винниченка. Сер. Проблеми методики фізикоматематичної і технологічної освіти. 2016. Вип. 10(2). С. 152-155. URL: http://nbuv.gov.ua/UJRN/nz_pmfm_2016_10\%282\%29_38 (дата звернення: 05.01.2020). 9. Реформа освіти та науки як засіб проти кризи : освітній портал. URL: http://osvita.ua/vnz/46908/ (дата звернення: 10.01.2020). 10. А. Кальдерон, 
головний радник з планування та науково-дослідної діяльності Королівського мельбурнського технологічного інституту, Австралія. Якою стане вища освіта до 2040 року : освітній портал. URL: https://osvita.ua/vnz/high_school/47910/ (дата звернення: 11.01.2020). 11. Щодо організації форм здобуття загальної середньої освіти : лист $\mathrm{MOH}$ №1/9-525 від 20.08.2019 p. URL: http://osvita.ua/legislation/Ser_osv/65524/ (дата звернення: 05.01.2020). 12. Про внесення змін до наказу Міністерства освіти і науки України від 12 січня 2016 року N 8: Наказ MOH N955 від 10.07.2019 p. URL: http://auc.org.ua/sites/default/files/sectors/u-137/indyvidualna.pdf. (дата звернення: 10.01.2020). 13. Реформа вищої освіти України: реалізація профільного закону В 2014-2016 pp. URL: https://parlament.org.ua/wpcontent/uploads/2016/12/HE-shadow-report-final.pdf (дата звернення: 10.01.2020).

\section{REFERENCES:}

1. Natroshvili S. H. Stratehichne upravlinnia vyshchym navchalnym zakladom : teoriia, metodolohiia, praktyka : monohrafiia. Kyiv : KNUTD, 2015. 320 s. 2. Pro osvitu : Zakon Ukrainy vid 05.09 .2017 r. № 2145-VIII. URL: https://zakon.rada.gov.ua/laws/show/2145-19 (data zvernennia: 05.01.2020). 3. Pro vyshchu osvitu : Zakon Ukrainy vid 01.07.2014 r. № 1556-VII. URL: https://zakon.rada.gov.ua/laws/show/1556-18 (data zvernennia: 05.01.2020). 4. Pro naukovu i naukovo-tekhnichnu diialnist : Zakon Ukrainy vid 24.11.2015 r. № 848-VIII. URL: https://zakon.rada.gov.ua/laws/show/848-19 (data zvernennia: 05.01.2020). 5. Kucherenko S. Yu. Cuchasnyi stan, tendentsii ta problemy rozvytku osvity v Ukraini. Ekonomichnyi visnyk universytetu. 2018. Vyp. 36(1). S. 51-59. URL: http://nbuv.gov.ua/UJRN/ecvu_2018_36\%281\%29_8 (data zvernennia: 15.01.2020). 6. Protasova N. H., Luhovyi V. I., Molchanova Yu. O. Reformuvannia osvity v Ukraini: derzhavno-upravlinskyi aspekt : navch.-nauk. vyd. Kyiv ; Lviv : NADU, 2012. 456 s. 7. Natsionalna dopovid pro stan i perspektyvy rozvytku osvity $v$ Ukraini. Nats. akad. ped. nauk Ukrainy / redkol.: V. H. Kremen (holova), V. I. Luhovyi (zast. holovy), A. M. Hurzhii (zast. holovy), O. Ya. Savchenko (zast. holovy)] ; za zah. red. V. H. Kremenia. Kyiv : Pedahohichna dumka, 2016. 448 s. 8. Shakhovska A. Osvitni aspekty staloho rozvytku Ukrainy. Naukovi zapysky Kirovohradskoho derzhavnoho pedahohichnoho universytetu imeni Volodymyra Vynnychenka. Ser. Problemy metodyky fizykomatematychnoi $i$ tekhnolohichnoi osvity. 2016. Vyp. 10(2). S. 152-155. URL: http://nbuv.gov.ua/UJRN/nz_pmfm_2016_10\%282\%29_38 (data zvernennia: 05.01.2020). 9. Reforma osvity ta nauky yak zasib proty kryzy : osvitnii portal. URL: http://osvita.ua/vnz/46908/ (data zvernennia: 10.01.2020). 10. A. Kalderon, holovnyi radnyk z planuvannia ta naukovo-doslidnoi diialnosti Korolivskoho melburnskoho tekhnolohichnoho instytutu, Avstraliia. Yakoiu stane vyshcha osvita do 2040 roku : osvitnii portal. URL: https://osvita.ua/vnz/high_school/47910/ (data zvernennia: 11.01.2020). 11. Shchodo orhanizatsii form zdobuttia zahalnoi serednoi osvity : lyst MON № 1/9-525 vid 20.08.2019 r. URL: http://osvita.ua/legislation/Ser_osv/65524/ (data zvernennia: 05.01.2020). 12. Pro vnesennia zmin do nakazu Ministerstva osvity $\mathrm{i}$ nauky Ukrainy vid 12 sichnia 2016 roku N 8 : Nakaz MON N 955 vid 10.07.2019 r. URL: http://auc.org.ua/sites/default/files/sectors/u-137/indyvidualna.pdf. (data zvernennia: 10.01.2020). 13. Reforma vyshchoi osvity Ukrainy: realizatsiia profilnoho zakonu $v$ 2014-2016 rr. URL: https://parlament.org.ua/wp-content/uploads/2016/12/HEshadow-report-final.pdf (data zvernennia: 10.01.2020). 


\section{CONCEPTUAL APPROACH TO THE FORMATION OF A NATIONAL EDUCATION DEVELOPMENT BASIS}

The article deals with the types of education such as formal, nonformal and informal based on the current legislation of Ukraine. Characteristics of ways of organizing training by certain types are given. It is determined that competently based standards characterize the content of education at the school level (State standard of elementary general education 2011, state standard of basic and complete secondary education 2011), vocational (introduction of state standards of vocational education based on competencies) and higher education (in accordance with the new Law of Ukraine «On Higher Education» 2014). The main problems of the modern educational policy with regard to the evaluation of its results and the inconsistency of the economic mechanism in the education mechanism with the principles of a market economy are highlighted. The ways of ensuring the development of the educational sector of the national economy are proposed: introduction of independent professional certification, reformation of the system of certification and professional development of pedagogical workers; reform of the management system and financial and economic mechanism of functioning of the education system in Ukraine; introduction of an external independent evaluation of the learning outcomes obtained at each educational level, including EIT; development of alternative educational projects; expanding the use of modern technologies in the management of education, organization of the educational process and control of learning outcomes and implementation of automated information systems; development and implementation of pilot projects to develop new mechanisms for managing and organizing educational activities. The conceptual approach of forming the foundations of the development of national education is proposed in three stages: in the framework of theoretical studies we propose to reveal the essence and role of education as an integral part of the functioning of the national economy; to define conceptual bases of national education development; to explore and study the world experience of transformation of educational processes, on the basis of which to distinguish the constituent characteristics adapted to the Ukrainian educational realities.

An approach to the analysis of the economic trends of the educational sector, taking into account absolute and specific indicators, will be established, which will identify internal and strategic problems of the industry and will allow to form concrete regulatory measures for improving the quality of educational services and modernization of the entire education system.

Keywords: national economy; education; educational sphere; educational policy; educational reform; types of education; ways of organizing education; sectoral analysis. 
Дун Чживэй, стажер-исследователь

(Винницкий национальный технический университет, г. Винница)

\section{КОНЦЕПТУАЛЬНЫЙ ПОДХОД ФОРМИРОВАНИЯ ОСНОВ РАЗВИТИЯ НАЦИОНАЛЬНОГО ОБРАЗОВАНИЯ}

В статье на основании действующего законодательства Украины исследованы виды образования: формальный, неформальный, информальный и охарактеризованы способы организации обучения по каждому из них. Выделены проблемы современной образовательной политики: отсутствие критериев оценки ее результатов и несоответствие действующего в образовании экономического механизма принципам рыночной экономики.

Предложены пути обеспечения развития образования национальной экономики: внедрение независимой профессиональной сертификации, реформирование системы аттестации и повышения квалификации педагогических работников; реформирование системы управления и финансово-экономического механизма функционирования системы образования; введение ВНО результатов обучения; развитие альтернативных образовательных проектов; расширение использования современных технологий в управлении образованием, организации образовательного процесса и контроле результатов обучения и внедрение автоматизированных информационных систем и др. Предложен концептуальный подход формирования основ развития национального образования. Он состоит из трех этапов: в пределах теоретических исследований предлагается раскрыть сущность и роль образования как неотьемлемой составляющей функционирования национальной экономики; определить концептуальные основы развития национального образования; исследовать и изучить мировой опыт трансформации образовательных процессов, на основе которого выделить составляющие характеристики, адаптированные для украинских образовательных реалий. Построен подход к анализу экономических тенденций образования с учетом абсолютных и удельных показателей, что позволит выявить внутренние и стратегические проблемы отрасли и позволит сформировать конкретные регулирующие меры по повышению качества образовательных услуг и модернизации всей системы образования.

Ключевые слова: национальная экономика; образование; образовательная сфера; образовательная политика; образовательная реформа; виды образования; способов организации обучения; секторный анализ. 